\title{
MORPHEA AND LICHEN SCLEROSUS IN A PATIENT WITH HYPORTHYROIDISM
}

\author{
Beata Bergler-Czop and Ligia Brzezińska-Wcisło
}

Department of Dermatology, Silesian Medical University in Katowice, Katowice, Poland

\begin{abstract}
SUMMARY - Thyroid gland is one of the key organs regulating the metabolism of carbohydrates, proteins and fats. Its primary function is connected with increase of the metabolic conversion of the body. Skin lesions are often one of the first symptoms of hypothyroidism. In a 71-year-old patient, skin lesions in the form of thickened areas with severe hyperkeratosis first appeared 12 years before. Eight years before, the patient was diagnosed with hypothyroidism of unknown cause. Upon admission, lesions were observed in the trunk area, left arm and vulva. These lesions had the appearance of brownish spots with hyperkeratosis. Initially, they were localized on the trunk, then involving upper limbs and neck area with time. Significant progression was present in the back area. In the anogenital area, porcelain-white discolorations were observed. Laboratory examinations were normal. During hospital stay, iv. ceftriaxone at a dose of $2.0 \mathrm{~g} /$ day for 10 days and intramuscular injection of vitamin B6 were administered, along with 10\% urea ointment for hyperkeratosis lesions as topical therapy. The patient had lesions in the form of skin induration and discoloration, with visible, very severe hyperkeratosis, which is not characteristic of changes of the scleroderma and lichen sclerosus type. These lesions caused diagnostic problems due to the atypical clinical appearance.
\end{abstract}

Key words: Hypothyroidism; Skin; Hyperkeratosis

\section{Introduction}

Thyroid gland is one of the key organs regulating the metabolism of carbohydrates, proteins and fats. Its primary function is connected with increase of the metabolic conversion of the body. Nowadays, the main cause of hypothyroidism are autoimmune diseases, most commonly Hashimoto's thyroiditis. Over $90 \%$ of patients are women. Hypothyroidism can also occur during the treatment of hyperthyroidism with radioiodine or after surgical removal. Less frequently, it is observed in endemic areas of iodine deficiency ${ }^{1}$.

Typical systemic symptoms of hypothyroidism include weight gain, excessive tiredness, feeling of cold, and constipation. Skin lesions are often one of the first symptoms of the disease. The skin has a tendency

Correspondence to: Beata Bergler-Czop, $M D$, Department of Dermatology, Silesian Medical University in Katowice, Francuska Street 20/24, 40-027 Katowice, Poland

E-mail: bettina2@o2.pl

Received June 7,2016, accepted June 27, 2017 to edema and dryness. A lack of facial expressions is frequently observed. Spilled swellings are most often connected with mucin deposition and they lead to myxedema. Hair is dry and tends to fall out. A typical symptom is also loss of the lateral one-third of eyebrows. Nails also grow slowly and are fragile. The tongue is enlarged and can interfere with speech. The whole skin can have a yellowish color, connected with a disorder of carotenoid metabolism. Within its reach, there may also be hyperkeratotic areas ${ }^{1-3}$.

Morphea and lichen sclerosus are known to be associated with an increased incidence of autoimmune disorders and autoantibodies, so the coexistence of other autoimmune diseases is expected. Localized scleroderma (morphea) and lichen sclerosus are the connective tissue diseases associated with sclerosis of the skin. They often appear in the same patient. Both may be localized or generalized. The etiology and precise mechanisms that trigger the cascade of molecular events that culminate in skin fibrosis are not clearly understood. Many inflammatory and immune path- 
ways are ultimately responsible for vascular changes, increased collagen production, and extracellular matrix proliferation.

There are many clinical subtypes of localized scleroderma, which include plaque profundus, bullous, linear, frontoparietal, segmental, and guttate types. Plaque type morphea is the commonest subtype ${ }^{4}$.

Morphea and lichen sclerosus are immune diseases that may be associated with other autoimmune disorders. The coexistence of two autoimmune diseases may not occur by chance, but could be attributed to autoimmune reactions elicited by recognition of common antigens ${ }^{4-7}$.

We present a case of a patient diagnosed with hypothyroidism, who had lesions in the form of thickened areas and skin hyperpigmentation, with visible hyperkeratosis diagnosed as localized scleroderma, which posed diagnostic problems due to atypical clinical presentation.

\section{Case Report}

A 71-year-old female patient reported the first skin lesions in the form of thickened areas with severe hyperkeratosis to have appeared 12 years before. Initially, they were localized on the trunk, then also involved upper limbs and neck area with time. Simultaneously, the patient complained of weight gain, feeling of cold and generalized dryness of the skin, but systemic symptoms were not diagnosed. In 2004, lesions in the form of porcelain-white discoloration spots appeared in the vulva area. Eight years before, the patient was diagnosed with hypothyroidism of unknown cause. Since that time, the patient was under endocrinological care. Currently, euthyroidism was achieved. In the meantime, due to progression of skin lesions, the patient was hospitalized several times at the Department of Dermatology. Procaine penicillin, cefuroxime, Piascledine ${ }^{\circledR}$, vitamin $\mathrm{E}$ and psoralen and ultraviolet $\mathrm{A}$ (PUVA) light therapy were used in the treatment. Due to the ambiguous clinical presentation of skin lesions, several skin biopsies were obtained for histopathologic examination. In 2006, the finding in specimens obtained from the trunk and left arm corresponded to 'morphea', while the one obtained from vulva was indicative of lichen sclerosus. In 2014, the patient was admitted to the Department of Dermatology, Silesian Medical University because of the significant progres-

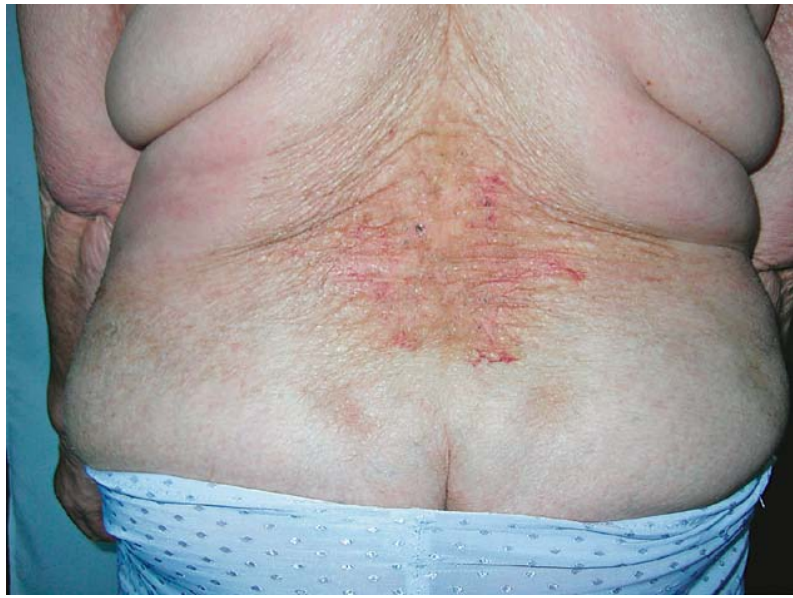

Fig. 1. Typical hyperkeratotic changes on the back.

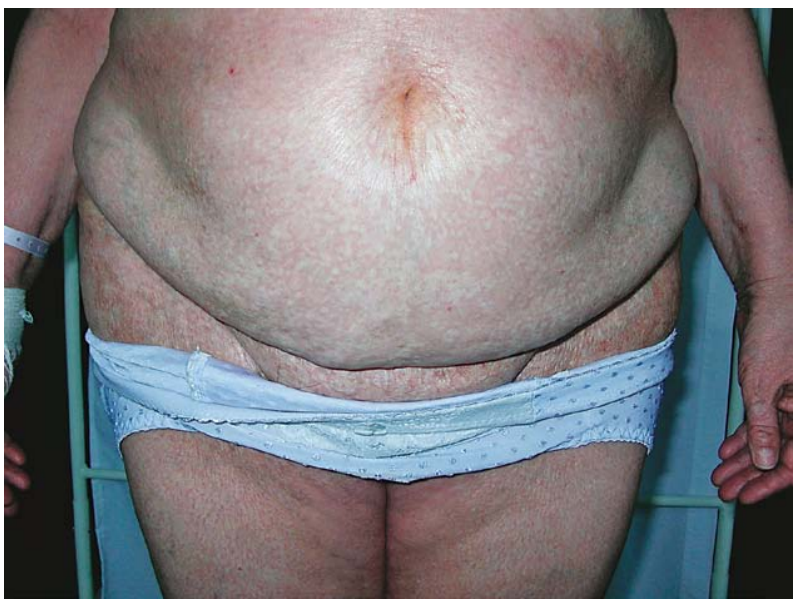

Fig. 2. Porcelain-white discolorations on the abdomen.

sion of skin lesions and hyperkeratosis accompanied by severe itch.

At admission, lesions were observed in the trunk, left arm and vulva areas. The lesions had the appearance of brownish spots with hyperkeratosis. Significant progression was observed in the back area. In the anogenital area, porcelain-white discolorations were observed. Peripheral lymph nodes were not enlarged. Mucous membranes and nail plates were free of lesions (Figs. 1 and 2).

Laboratory tests: erythrocyte sedimentation rate, morphology with peripheral blood smear, iron level, electrolytes, AspAT, ALAT, GGTP, bilirubin, creatinine, urea, protein, protein electrophoresis, $\mathrm{CPK}$, aldolase, triglycerides, cholesterol, joint reactions (Latex-R, Waaler-Rose test, ASO), urinalysis and glucose levels were normal. Chest radiograph was without ab- 
normalities. Esophagography indicated disturbed swallowing partially, with flabby esophagus, slightly widened in the middle and lower segments (with weakened peristalsis), and medium contrast retention. $\mathrm{Ab}-$ dominal ultrasound revealed increased fatty liver with a small cyst in the right lobe, cysts of about $30 \mathrm{~mm}$ in both renal pelvis, small cortical cysts, and signs of lipofibromatosis. Mycologic diagnostics (microscopic examination and culture, swabs taken from the back area) proved negative. Capillaroscopy showed no abnormalities. Histopathologic examination (back area) showed atrophic epidermis with excessive and partial keratosis, with the formation of subepidermal blisters. In the dermis, edema and unification of the structure with hyperplasia of capillary vessels and perivascular lymphocyte infiltrations were observed. Microscopic image was quite ambiguous. The results were typical for lichen sclerosus and morphea. ANA2 antibodies were not detected by indirect immunofluorescence on Hep2 cells. IgG and $\operatorname{lgM}$ antibodies against Borrelia burgdorferi were negative.

During stay at the Department, the patient was administered iv. ceftriaxone at a dose of $2.0 \mathrm{~g}$ per day for 10 days and intramuscular injections of vitamin B6, along with $10 \%$ urea ointment for hyperkeratosis lesions as topical treatment. When improvement was achieved, the patient was discharged and referred to Dermatologic Outpatient Clinic. Now, the patient is under outpatient care. Skin changes are less pigmented and the skin is more elastic.

A written informed consent was obtained from the patient for publication of this case report and any accompanying images.

\section{Discussion}

The main function of the thyroid gland is controlling metabolic processes in the body. Disorders of its functions cause multi-organ changes, of which skin lesions are some of the most noticeable. Hypothyroidism is mainly caused by autoimmune disorders, the most common of these being Hashimoto's thyroiditis. It can also occur after treatment of hyperthyroidism or in endemic regions with iodine deficiency ${ }^{1}$. In some cases, it is not possible to determine the cause of the disease; in such a situation, the patient is managed as described in this paper. The literature contains reports on many disorders of the skin and subcutaneous tissue, which are described as typically coexisting with thyroid diseases ${ }^{4}$. Frisch et al..$^{5}$ report on vitiligo and alopecia areata as the most typical disorders. They examined the connection of non-segmental vitiligo with autoimmune thyroid diseases. Their prospective study involved 626 patients with vitiligo. The level of antibodies against thyroid peroxidase was determined and was positive in 131 patients. The authors also found vitiligo associated with thyroid peroxidase antibodies to have different clinical features from vitiligo without positive antibodies ${ }^{6}$.

Kasumagic-Halilovic et al. also investigated coexistence of vitiligo and thyroid disease. The aim of their study was to determine the prevalence and significance of antinuclear antibodies (ANA) and anti-thyroid peroxidase (anti-TPO) antibodies in patients with vitiligo. In their prospective case-control study, the prevalence of ANA and anti-TPO was compared between 40 patients with these dermatoses and 40 healthy volunteers. ANA was positive in 7 (17\%) patients and this result was slightly higher than in the control group $(\mathrm{n}=2 ; 5 \%)$. Anti-TPO was positive in $11(27 \%) \mathrm{pa}^{-}$ tients. In the control group, only two (5\%) subjects had positive anti-TPO result. The results obtained indicated a significant relationship between leukoderma and autoimmune thyroid disease ${ }^{8}$. In contrast, antinuclear antibodies have a limited diagnostic value. Thornsberry and English investigated cases of granuloma annulare that appeared in the course of both hypoand hyperthyroidism ${ }^{9}$.

Bjekic et al. tried to determine some risk factors for lichen sclerosus in men. Out of 73 patients with lichen sclerosus, 9 men had various thyroid gland diseases ${ }^{7}$. Ghayad et al. included 36 scleroderma patients in their study and found 7 abnormal cases including 6 cases of hypothyroidism secondary to autoimmune thyroiditis and one case of hyperthyroidism secondary to Graves' disease. In the hypothyroid subgroup, 3 cases presented localized systemic sclerosis and diffuse systemic sclerosis each, while Sjögren's syndrome was found in two of these patients ${ }^{6}$.

There also are literature reports on coexistence of autoimmune thyroid diseases, in particular BasedowGraves' disease, and chronic urticaria ${ }^{10}$. Chronic urticaria is defined as the presence of evanescent wheals that persist for more than six weeks. Over half of all cases of chronic idiopathic urticaria have autoimmune mechanism with autoantibodies of mainly high affinity to the receptor (FcsRI) immunoglobulin $\mathrm{E}(\mathrm{IgE})$. 
This corresponds to the hypothesis on strong relationship between chronic urticaria and autoimmune diseases such as rheumatoid arthritis, thyroid diseases, systemic lupus erythematosus (SLE), celiac disease, Sjögren's syndrome and diabetes type $1^{11}$. Yadav et al. report on slightly different results. They also examined the relationship between thyroid diseases and chronic idiopathic urticaria. According to these authors, the presence of thyroid autoantibodies was observed in only $5 \%$ of patients in this group ${ }^{12}$. To our knowledge, there are no literature reports similar to our case with unusual appearance of morphea and lichen sclerosus complicated by significant hyperkeratosis. The only literature report related to such a finding is the one by Kreuter et al. who tested 532 patients diagnosed with lichen sclerosus. Anti-thyroid antibodies were more frequently detected in patients with lichen sclerosus of the skin as compared with control group ${ }^{13}$.

Melcescu et al. tried to estimate the coexistence of Graves' disease, hypoparathyroidism and connective tissue diseases, mainly SLE. However, study results did not indicate such a relationship ${ }^{14}$. Allam and Ghozzi ${ }^{15}$ and Berlger-Czop et al. ${ }^{16}$ presented cases of scleromyxedema associated with hypothyroidism. The disease is rare and connected with the accumulation of mucin deposits, fibroblast proliferation and fibrosis. In patients without thyroid disease, coexistence with paraproteinemia (mainly IgG, lambda type) is observed.

Systemic changes include gastrointestinal tract, skeletal muscle, lungs, cardiovascular system, kidneys and central nervous system, and lead to severe complications. Numerous reports also describe pretibial myxedema as typical comorbidity in the course of hyperthyroidism.

Lohiya et al. presented a 62-year-old patient with Basedow-Graves' disease without ophthalmopathy, but with pretibial myxedema. In addition to skin lesions, the patient complained of the symptoms of anxiety, insomnia and fatigue lasting for up to 6 months. The patient also described chest pain combined with palpitation and $25-\mathrm{kg}$ weight loss. Skin lesions were accompanied by itching and burning ${ }^{17}$. Pretibial myxedema is an autoimmune manifestation of BasedowGraves' disease. Vannucchi et al. treated pretibial myxedema in the course of Basedow-Graves' disease using dexamethasone with lidocaine and saline solution passed via mesotherapy $\leq 4 \mathrm{~mm}$ needles into the dermis or first layer of subcutaneous fat. The preparation was administered once a week for 6 weeks. Improvement of local state and $\sim 15 \%$ reduction of lesion thickness on ultrasonography were observed in patients, mainly in the dermis ${ }^{18}$.

Zoabi et al. studied thyroid function in 100 patients with psoriasis vulgaris. The following parameters were determined: TSH, T3, T4, anti-TPO and anti-thyroglobulin. In patients with psoriasis, the increase of anti-TPO was found in 9 (9\%) psoriasis patients as compared to $3(5.6 \%)$ patients in control group. The increase of anti-TG was observed in $3(3 \%)$ patients with psoriasis as compared to one $(1.8 \%)$ patient in control group. The increase of TSH was demonstrated in $5(5 \%)$ patients with psoriasis as compared to 3 $(5.6 \%)$ patients in control group. T3 levels were abnormal in 3 patients and T4 levels in 2 patients with psoriasis, whereas the results in control group patients were normal. The study did not find statistically significant difference in thyroid function between psoriasis patients and control group ${ }^{19}$.

Kavala et al. studied correlations between the occurrence of thyroid diseases and pemphigus vulgaris. This study included 80 patients with pemphigus vulgaris and 80 healthy volunteers. Patients were evaluated for the levels of fT3, fT4, TSH, antibodies, antiTPO and anti-thyroglobulin antibodies (Tg). Primary thyroid disease was diagnosed on the basis of the following diagnostic criteria: positive antibodies and thyroid dysfunction. Significant changes in serum profile were recorded in $16 \%(13 / 80)$ of pemphigus vulgaris patients and 5\% (4/80) of control subjects. Positive anti-thyroid antibodies (anti-TPO and anti-Tg) were observed in 7 (9\%) patients with pemphigus vulgaris and one (1.2\%) control subject. Hashimoto's disease was diagnosed in 9 patients with pemphigus vulgaris. Moreover, this disease was found to be more prevalent in the form of pemphigus vulgaris occupying mucous membranes. Considering the results obtained, the authors suggested that pemphigus vulgaris could coexist with autoimmune thyroid diseases, especially Hashimoto's disease ${ }^{20}$.

\section{Conclusion}

We presented a rare case of a patient diagnosed with hypothyroidism. The patient had lesions in the form of induration and discoloration of the skin, with visible, very severe hyperkeratosis, which is not charac- 
teristic of scleroderma and lichen sclerosus type of lesions. These lesions caused diagnostic problems due to their atypical clinical appearance. Considering the association of autoimmune diseases and thyroid diseases, we suggest to perform thyroid screening in all patients with morphea and lichen sclerosus.

\section{References}

1. Horita M, Takahashi N, Seike M, Nasu S, Takaki R. A case of primary biliary cirrhosis associated with Hashimoto's thyroiditis, scleroderma and Sjögren's syndrome. Intern Med. 1992; 31:418-21.

2. Pedullá M, Fierro V, Papacciuolo V, Alfano R, Ruocco E. Atopy as a risk factor for thyroid autoimmunity in children affected with atopic dermatitis. J Eur Acad Dermatol Venereol. 2014; 28:1057-60. doi: 10.1111/jdv.12281

3. Courcoutsakis NA, Tatsi C, Patronas NJ, Lee CC, Prassopoulos PK, Stratakis CA. The complex of myxomas, spotty skin pigmentation and endocrine overactivity (Carney complex): imaging findings with clinical and pathological correlation. Insights Imaging. 2013;4:119-33.

4. Hassan I, Arif T, Anwar P. Thyroid dysfunctions in morphoea: a preliminary report. Indian J Dermatol Venereol Leprol. 2014;80:579. doi: 10.4103/0378-6323.144230

5. Frisch M, Nielsen NM, Pedersen BV. Same-sex marriage, autoimmune thyroid gland dysfunction and other autoimmune diseases in Denmark 1989-2008. Eur J Epidemiol. 2014;29: 63-71. doi: 10.1007/s10654-013-9869-9

6. Ghayad E, Tohme A, Haddad F, Haddad C, Choueiry R. Scleroderma with anomalies of the thyroid function. 7 cases. Ann Med Interne (Paris). 1997;148:307-10.

7. Bjekić M, Šipetić S, Marinković J. Risk factors for genital lichen sclerosus in men. Br J Dermatol. 2011;164:325-9. doi: 10.1111/j.1365-2133.2010.10091.x

8. Kasumagic-Halilovic E, Ovcina-Kurtovic N, Jukic T, Karamehic J, Begovic B, Samardzic S. Vitiligo and autoimmunity. Med Arh. 2013;67:91-3.
9. Thornsberry LA, English JC $3^{\text {rd }}$. Etiology, diagnosis, and therapeutic management of granuloma annulare: an update. Am J Clin Dermatol. 2013;14:279-90.

10. Ruggeri RM, Imbesi S, Saitta S, Campennì A, Cannavò S, Trimarchi F, Gangemi S. Chronic idiopathic urticaria and Graves' disease. J Endocrinol Invest. 2013;36:531-6.

11. Fraser K, Robertson L. Chronic urticaria and autoimmunity. Skin Ther Lett. 2013;18:5-9.

12. Yadav S, Kanwar A, Parsad D, Minz R. Chronic idiopathic urticaria and thyroid autoimmunity: perplexing association. Indian J Dermatol. 201;58:325. doi: 10.4103/0019-5154.113932

13. Kreuter A, Kryvosheyeva Y, Terras S, Moritz R, Möllenhoff K, Altmeyer P, Scola N, Gambichler T. Association of autoimmune diseases with lichen sclerosus in 532 male and female patients. Acta Derm Venereol. 2013;93:238-41.

14. Melcescu E, Kemp EH, Majithia V, Vijayakumar V, Uwaifo GI, Koch CA. Graves' disease, hypoparathyroidism, systemic lupus erythematosus, alopecia, and angioedema: autoimmune polyglandular syndrome variant or coincidence? Int J Immunopathol Pharmacol. 2013;26:217-22.

15. Allam M, Ghozzi M. Scleromyxedema: a case report and review of the literature. Case Rep Dermatol. 2013;5:168-75.

16. Bergler-Czop B, Brzezińska-Wcisło L, Rogala-Poborska I. Nietypowy przypadek liszaja śluzowatego twardzinowego towarzyszącego chorobie tarczycy. Dermatol Klin. 2007;9:97-9. (in Polish)

17. Lohiya S, Lohiya V, Stahl EJ. Pretibial myxedema without ophthalmopathy: an initial presentation of Graves' disease. Am J Med Sci. 201;346:73-5.

18. Vannucchi G, Campi I, Covelli D, Forzenigo L, Beck-Peccoz P, Salvi M. Treatment of pretibial myxedema with dexamethasone injected subcutaneously by mesotherapy needles. Thyroid. 2013;23:626-32.

19. Zoabi A, Ziv M, Rozenman D, Lovoshitski R. Prevalence of thyroid abnormalities among psoriatic patients. Harefuah. 2012;151:566-9, 605-6.

20. Kavala M, Kural E, Kocaturk E, Zindanci I, Turkoglu Z, Can $B$. The evaluation of thyroid diseases in patients with pemphigus vulgaris. Sci World J. 2012;2012:146897. 


\title{
Sažetak
}

\section{MORFEA I SKLEROTIČNI LIHEN KOD BOLESNICE S HIPOTIREOZOM}

\author{
B. Bergler-Czop i L. Brzezinska-Wisto
}

Štitna žlijezda jedan je od ključnih organa koji regulira metabolizam ugljikohidrata, bjelančevina i masti. Njezina glavna funkcija povezana je s porastom konverzije u organizmu. Kožne promjene često su jedan od prvih simptoma hipotireoze. Kod naše bolesnice u dobi od 71 godine kožne promjene u vidu zadebljanih područja uz tešku hiperkeratozu prvi put su se pojavile 12 godina ranije, a osam godina ranije dijagnosticirana joj je hipotireoza nepoznatog uzroka. Kod prijma bolesnice opažene su promjene u području trupa, lijeve ruke i vulve. Te promjene izgledale su poput smeđkastih točkica s hiperkeratozom. U početku su bile lokalizirane na trupu, da bi kasnije s vremenom zahvatile gornje udove i područje vrata. Značajna progresija lezija zabilježena je na leđima. U anogenitalnom području opažene su porculanski bjelkaste mrlje na koži. Laboratorijski testovi bili su normalni. Za vrijeme hospitalizacije bolesnica je primala ceftriakson iv. u dozi od 2,0 g/dan kroz 10 dana i intramuskularne injekcije vitamina B6, uz lokalnu terapiju kremom s $10 \%$ ureje za hiperkeratotične lezije. Bolesnica je imala promjene u obliku kožne induracije i diskoloracije, uz vidljivu i vrlo tešku hiperkeratozu, što nije karakteristično za promjene tipa sklerodermije i skleroznog lihena. Ove promjene izazvale su dijagnostičke probleme zbog netipičnog kliničkog izgleda.

Ključne riječi: Hipotireoza; Koža; Hiperkeratoza 